\title{
Host Range and Virulence of a Fungal Pathogen for Control of Giant Salvinia (Salvinia molesta)
}

\author{
Clyde D. Boyette ${ }^{1}$, Robert E. Hoagland ${ }^{2}$, Lawrence R. Higgenbotham ${ }^{3}$, H. Lynn Walker ${ }^{3}$, \\ James A. Young ${ }^{3}$, Kenneth C. Stetina ${ }^{1}$
}

${ }^{1}$ USDA-ARS, Biological Control of Pests Research Unit, Stoneville, MS, USA

${ }^{2}$ Crop Production Systems Research Unit, Stoneville, MS, USA

${ }^{3}$ Louisiana Tech University, Ruston, LA, USA

Email: doug.boyette@usda.gov

How to cite this paper: Boyette, C.D., Hoagland, R.E., Higgenbotham, L.R., Walker, H.L., Young, J.A. and Stetina, K.C. (2021) Host Range and Virulence of a Fungal Pathogen for Control of Giant Salvinia (Salvinia molesta). American Journal of Plant Sciences, 12, 444-454.

https://doi.org/10.4236/ajps.2021.123029

Received: September 30, 2020

Accepted: March 28, 2021

Published: March 31, 2021

Copyright $\odot 2021$ by author(s) and Scientific Research Publishing Inc. This work is licensed under the Creative Commons Attribution International License (CC BY 4.0).

http://creativecommons.org/licenses/by/4.0/

\begin{abstract}
A teleomorph of the fungus Botryosphaeria rhodina (Berkeley et Curtis) von Arx, $(B r)$ was evaluated as a bioherbicide for control of giant salvinia (Salvinia molesta D.S. Mitchell) under greenhouse conditions and in small-scale field trials. We found that fungal mycelium was highly infective and could be rapidly produced $(48+\mathrm{h})$ in soy flour-cornmeal liquid media contained in shake flasks or fermenters. A dew period was not required to achieve infection and mortality of inoculated plants. A surfactant (Silwet L-77, a polyalkyleneoxide modified heptamethyl-trisiloxane) incorporated in the fungal formulation was required for $B r$ to infect and kill plants. Infection and mortality occurred rapidly (within $48 \mathrm{~h}$ after treatment), and re-growth of treated plants did not occur. In replicated field trials, $B r$ controlled giant salvinia $\sim 95 \%$. Br also infected other plants, such as common salvinia ( $S$. minima Baker), and Azolla filiculoides Lam., as determined in ongoing host range research. However, no symptomatology was observed on several economically important crop species, such as rice (Oryza sativa L.), corn (Zea mays L.), and several woody species such as bald cypress (Taxodium distichum L.) and loblolly pine (Pinus taeda L.) occurring in areas where giant salvina occurs that would be subject to contact with releases of $B r$. These results suggest that this teleomorph of Botryosphaeria rhodina has potential as a bioherbicide for controlling this onerous aquatic weed.
\end{abstract}

\section{Keywords}

Biological Control, Botryosphaeria rhodina (Berkeley et Curtis) Von Arx, Fungal Phytopathogen, Salvinia molesta D.S. Mitchell, Aquatic Weed

\section{Introduction}

Aquatic ecosystems throughout the world are threatened by invasive aquatic 
weeds, both floating and submerged. Some of these weeds, such as water hyacinth (Eichhornia crassipes [Mart.] Solms), alligator weed (Alternanthera philoxeroides Mart.), water lettuce (Pistia stratiotes (L.), Griseb.), and giant salvinia (Salvinia molesta D.S. Mitchell), although relatively minor problems in their native range, have become major invasive weeds of aquatic habitats when introduced into other parts of the world [1]. Giant salvinia is an exotic, invasive, aquatic fern, native to Brazil and Argentina. It was likely brought into the US as a novelty aquarium plant, and/or as an aquarium or water garden plant contaminant, listed in 1981 as a Federal Noxious Weed [2]. Giant salvinia was first reported outside of cultivation in the US in 1995 in southeastern South Carolina [3]; the weed was subsequently reported in Texas and Louisiana in 1998. Since then, it has "escaped" or re-introduced and can now be found as far west as the Hawaiian Islands, east into the peninsula of Florida, and north into Virginia [2] and more recently in central Mississippi [4] and Arkansas [5] [6]. Once it infests a waterway (Figure 1), its spread is facilitated by flowing water, boats, boat trailers and other recreational watercraft (Figure 1(a) \& Figure 1(b)). Along with water hyacinth, giant salvinia is often deemed one of the worst aquatic weeds worldwide [7] [8].

Giant salvinia infestations provide ideal habitats for mosquitoes that can transmit various human diseases such as encephalitis, dengue fever, and malaria [9] [10], as well as St. Louis encephalitis and Venezuelan equine encephalitis [9] [11]. In addition to the US, this weed has been introduced in $>20$ countries worldwide [12], including Australia, where it has become a major weed problem and the subject of extensive research [13].

Several chemical herbicides have been evaluated for giant salvinia control [14]. Diquat dibromide and glyphosate are recommended for giant salvinia control in Louisiana [15]. Penoxsulam and bispyribac-sodium have also shown promising results [16]. Mechanical removal of giant salvinia can be effective in localized situations, such as in ponds. However, under ideal conditions, giant salvinia biomass can double in 3 days, reaching levels of 400,000 kg/fresh weight per ha [13] [17]. These growth rates often exceed the capability of control by mechanical removal or herbicide treatment [13] [18]. For effective giant salvinia control, it is prudent to treat newly infested areas as soon as possible, when plant populations are smaller, and plants are at their most vulnerable stages [2].

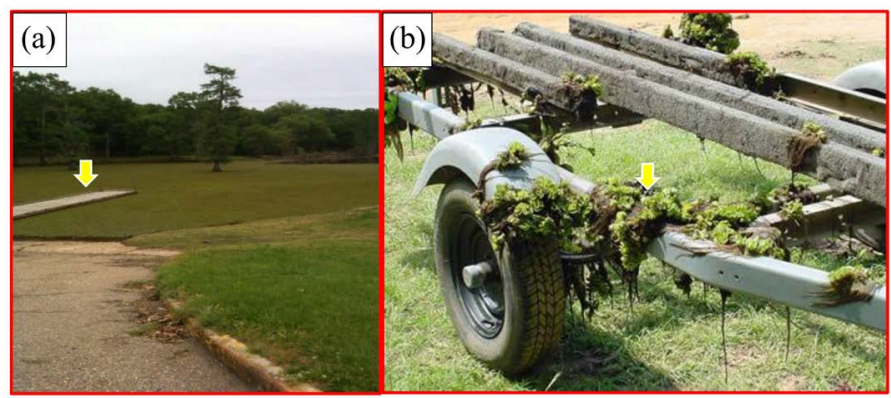

Figure 1. (a) Lake infested with $S$. molesta (arrow indicates pier extending into water); (b) Boat trailer contaminated with $S$. molesta (denoted by arrow). 
Void of its natural enemies, giant salvinia can become invasive, replacing native flora, and disrupting ecosystems [13]. In Australia the salvinia weevil (Cyrtobagous salviniae Calder and Sands (Coleoptera: Curculionidae), native to South America, has shown promise as a biological control agent against this weed [12] [13]. Populations of 300 weevils $/ \mathrm{m}^{2}$ have provided successful biocontrol [12] [13]. This insect has been introduced into several countries, including the U.S., with promising results [2] [13] [19]-[24]. This insect also shows promise for controlling a related species, common salvinia [25].

However, control of giant salvinia using this agent is less than satisfactory in the cooler regions of its distribution, probably due to the insects' inability to cope with colder climates.

While conducting host range experiments of a fungus isolated from sicklepod [Senna obtusifolia (L.) H.S. Irwin \& Barneby] that was being evaluated as a bioherbicide against sicklepod, $S$. molesta plants [concurrently cultured for bioherbicidal experiments with a different pathogen (Myrothecium verrucaria (Alb. \& Schwein.) Ditmar:Fr.)] were inoculated with mycelial fragments formulated in the surfactant of the $S$. obtusifolia isolate formulated in the surfactant Silwet L-77 (a polyalkyleneoxide modified heptamethyltrisiloxane) surfactant (Monsanto Chemical Corporation, St Louis, MO). The fungus was identified as a teleomorph of Botryosphaeria rhodina (Berkeley et Curtis) von Arx, (Br). Botryosphaeria is a genus of Ascomycetous plant pathogenic fungi in the family Botryosphaeriaceae, encompassing almost 200 species, many of which are important disease-causing agents of various important agricultural crops [26]. The objectives of the present research were to determine the host range, virulence, and field efficacy of this isolate of $B$. rhodina for biological control of this problematic weed.

The objectives of the present research were to determine the host range, virulence, and field efficacy of this isolate of $B$. rhodina for biological control of this problematic weed.

\section{Materials and Methods}

\subsection{Pathogen Isolation}

Diseased petioles and stems of sicklepod (L.) H.S. Irwin \& Barneby were collected from natural infestations in Louisiana and Mississippi. Diseased tissues were surface sterilized in $0.05 \% \mathrm{NaOCl}$ (bleach) for $1 \mathrm{~min}$, then the sections were placed on potato-dextrose agar (PDA) amended with the antibiotics, chloramphenicol $\left(0.75 \mathrm{mg} \cdot \mathrm{ml}^{-1}\right)$ and streptomycin sulfate $\left(1.25 \mathrm{mg} \cdot \mathrm{ml}^{-1}\right)$ in Petri plates.

\subsection{Test Plant Propagation}

For all experiments, stock populations of $S$. molesta (obtained from the U.S. Army Corps of Engineers Waterways, Experiment Station, Vicksburg, MS, USA), were grown in deionized water contained in $189.25 \mathrm{~L}$ polystyrene lives- 
tock watering vessels. The plants were grown in the greenhouse with temperatures ranging from $25^{\circ} \mathrm{C}-30^{\circ} \mathrm{C}$ with $40 \%-90 \%$ relative humidity (RH). The photoperiod was $12 \mathrm{~h}$ with $1650 \mu \mathrm{mol} \cdot \mathrm{m}^{-2} \cdot \mathrm{s}^{-1} \mu \mathrm{E} \cdot \mathrm{m}^{-2} \cdot \mathrm{s}^{-1}$ measured at midday. For all greenhouse experiments, ten $S$. molesta plants (in the primary to secondary stages of growth) were collected from the stock population and placed in $15.0 \times 30.0 \mathrm{~cm}$ clear plastic containers, containing $1.5 \mathrm{~L}$ distilled, deionized water. Following inoculation, containers with plants were mounted on benches in the greenhouse with conditions as described previously.

\subsection{Host Range Experiments}

Some weed seed were (purchased from Azlin Seed Co., (Leland, MS, 38756). Other weed seed were collected from local sites. Seeds of individual weed species (planted in a 1:1 potting mix of a commercial potting mix and soil, contained in plastic trays, $25 \times 52 \mathrm{~cm}$ ). Germinated seeds were transplanted into $10 \mathrm{~cm}^{2}$ plastic pots and grown under greenhouse conditions as described until plants were ca $10 \mathrm{~cm}$ in height. Vegetable seeds were purchased from W. Atlee Burpee Seed Co., Warminster, PA., USA, and crop seeds were purchased from Leland Feed and Seed Co, Leland, MS, USA. Tree species, such as cypress, pine, oak, and stone fruit saplings were purchased from local nurseries, or collected locally. Plants were inoculated by spraying homogenized, raw fermentation product in $0.2 \%$ Silwet L-77 surfactant at a rate of ca $200 \mathrm{l} \cdot \mathrm{ha}^{-1}$ using a $\mathrm{CO}_{2}$ backpack sprayer (R \& D Sprayers, Opalousas, LA, USA). Inoculated plants were placed in darkened dew chambers (Model I-36 DL; Percival Sci. Ind., Perry, IA, USA) at $25^{\circ} \mathrm{C}$, $100 \mathrm{RH}$ for $16 \mathrm{~h}$, and then placed on greenhouse benches. Control plants for each species were treated with surfactant only. Giant salvinia were included to verify pathogen virulence. Plants were rated 14 days after treatment for mortality and dry weight reduction. Dry weight measurements were determined in untreated and treated plants that had been excised at the soil line and died in an oven $\left(85^{\circ} \mathrm{C}, 48 \mathrm{~h}\right)$. The experiments were conducted twice with 3 sets of 10 plants for each experiment. Mortality and dry-weight reductions for each species were evaluated using the t-test [27] to compare the treatment means with the means of the respective controls.

\subsection{Pathogen Virulence Experiments}

\subsubsection{Greenhouse Experiments}

S. molesta plants that were in the primary and secondary stages of growth were collected from the stock population and placed in $15.0 \times 30.0 \mathrm{~cm}$ clear plastic containers, 10 plants per container. $1.5 \mathrm{~L}$ distilled, deionized water. The plants were inoculated with homogenized, raw $\mathrm{Br}$ fermentation product (containing $50 \mathrm{~g} \cdot \mathrm{L}^{-1} \mathrm{Br}$ mycelium) in $0.2 \%$ Silwet L-77 surfactant, at a rate of ca $200 \mathrm{~L} \cdot \mathrm{ha}^{-1}$ using a $\mathrm{CO}_{2}$ backpack sprayer ( $\mathrm{R} \& \mathrm{D}$ Sprayers, Opalousas, LA, USA). Control plants were sprayed with water and surfactant only. Following inoculation, the plants were placed on greenhouse benches with conditions as previously de- 
scribed. Plants were monitored at $12 \mathrm{~h}$ intervals for disease kinetic studies, and determinations of mortality and dry weight reductions over a $48 \mathrm{~h}$ period after treatment. A subjective visual disease severity rating scale (per plant basis) was used to estimate disease progression where $0=$ no disease, $1=1 \%-25 \%$ disease, $2=26 \%-50 \%$ disease, $3=51 \%-75 \%$ disease, $4=76 \%-99 \%$ disease, and $5=$ plant death [28]. Disease ratings $\leq 2.0$ were considered "slight", 2.1 - 3.9 were considered "moderate", and $\geq 4.0$ were considered "severe". Surviving plants were excised at the soil line, oven-dried for $48 \mathrm{~h}$ at $85^{\circ} \mathrm{C}$, weighed, and the percent biomass reduction was determined. Treatments were replicated four times, for a total of 48 individual plants per treatment. The experiment was repeated over time, and data were averaged following Bartlett's test for homogeneity of variance [29]. A randomized complete block experimental design with four replications was utilized. The mean percentage of plant mortalities and biomass reductions were calculated for each treatment and were subjected to Arcsin transformation. The transformed data were statistically compared using analysis of variance (ANOVA) at the 5\% probability level. Results were back-transformed to the original measurements (percentages) for presentation. Data were analyzed via the PROC MIXED function of SAS v9.3 (SAS Institute, Cary, NC, USA) using a least significant difference of 0.05 . In the disease kinetic studies, best-fit regression analysis was also utilized.

\subsubsection{Field Experiments}

$S$. molesta test plots $\left(1 \mathrm{~m}^{2}\right)$ were established in a freshwater pond near Lake Bistineau, LA, USA $\left(32^{\circ} 51^{\prime} \mathrm{N} \times 93^{\circ} 31^{\prime} \mathrm{W}\right)$ that was naturally infested with $S$. molesta. $S$. molesta plants were in the primary and secondary growth stages at treatment. Each plot contained $\sim 75 S$. molesta plants. Homogenized, raw fermentation product in $0.2 \%$ Silwet L-77 surfactant as described was sprayed at a rate of $\sim 200 \mathrm{~L} \cdot \mathrm{ha}^{-1}$ using a $\mathrm{CO}_{2}$ backpack sprayer as described. $S$. molesta mortality was assessed visually using the paired t-test [28] by comparing the percentage of necrotic tissue in the treated plots with the plant tissue in the paired untreated control plots [28]. The experiment consisted of three replications of $B r$-treated and untreated test plots. The experiment was repeated, and data from the two experiments were averaged, following subjection to Bartlett's test for homogeneity of variance [28].

\section{Results and Discussion}

\subsection{Pathogen Isolation}

Fungal emergence from the infected tissues did not occur within $48 \mathrm{~h}$ and considerable purported saprophytic fungi (Rhizopus, Mucors, Penicillium, and other spp.) began to contaminate the plates, the isolation process was repeated, except that the infected plant tissues were allowed to soak in the bleach solution for periods ranging from $2 \mathrm{~min}$ to $30 \mathrm{~min}$. Little differences in contamination were observed between 1 to 2 min bleach soaking, and no fungal growth occurred af- 
ter 20 min soaking. However, after the 15 min. soaking treatment, fungal growth began to appear, but only after incubation for $120 \mathrm{~h}$ at $25^{\circ} \mathrm{C}$. Advancing edges of fungal colonies were transferred to PDA and incubated for 5 days at $25^{\circ} \mathrm{C}$ under alternating 12-h light/12-h dark regimens, provided by cool white fluorescent lights. The fungus was sub-cultured on PDA without antibiotics, and preserved under refrigeration in sterilized sandy loam soil ( $25 \%$ water holding capacity), on sterile silica gel containing skim milk or on PDA slants stored at $4^{\circ} \mathrm{C}$. Due to the extreme length of time required to recover the pathogen from infected tissue, we hypothesized that this disease may be of a latent nature.

\subsection{Host Range Experiments}

No symptomatology was observed on several economically important crop species such as Oryza sativa (rice), Zea mays (corn), and woody species such as Taxodium distichum (bald cypress) and Pinus taeda (loblolly pine), which are often grown in areas where giant salvina occurs, and could be subject to contact with releases of $\mathrm{Br}$ (Table 1 ). Mortality and dry weight reductions $\leq 50 \%$ occurred on: Alternanthera philoxeroides (alligator weed); and Triadica sebifera (Chinese tallow tree); Pueraria montana (kudzu); Senna obtusifolia (sicklepod); Sesbania exaltata (hemp sesbania), and dry weight reductions $\leq 15 \%$ (with no mortality) occurred on Amaranthus palmeri (Palmer amaranth), A. retroflexus (redroot pigweed), A. tuberculatus (tall waterhemp). Mortality and dry weight reductions $\geq 95 \%$ occurred on: $S$. molesta (giant salvinia); $S$. minima (common salvinia); Azolla filiculoides (red azolla); and Lemna minor (Duckweed).

\subsection{Pathogen Virulence}

\subsubsection{Greenhouse}

We found that $B r$ fungal mycelium was highly infective to host weeds and could be rapidly produced $(48 \mathrm{~h})$ in liquid media in shake flasks or fermenters. Disease on $S$. molesta incited by $B r$ progressed in a linear fashion from 1 to 48 HAT under greenhouse conditions, with severe disease (rating of 4.0) occurring $\sim 40$ HAT. Disease eventually increased to 5.0 at 48 HAT (Figure 2). Re-growth of treated plants did not occur (Table 2, Figure 3).

\subsubsection{Field}

Field bioassays corroborated our findings in greenhouse experiments. Over $80 \%$ of $S$. molesta was controlled within $24 \mathrm{~h}$ after inoculation (data not shown), with maximum mortality rates (95\%) and dry weight reduction (98\%) occurring within 72 HAT (Figure 4). Disease symptoms were characterized by rapid necrosis which began to occur within $6 \mathrm{~h}$ after inoculation. Because of this rapid necrosis, it is possible that secondary metabolites, such as cellulolytic enzymes, or an unknown phytotoxin(s) are produced by this fungus. Further characterization of these enzymes and their roles in the development of infectivity, necrosis, and mortality of target weeds are subjects of further research. 
Table 1. Known host range of Botryosphaeria rhodina on various herbaceous and woody plant species ${ }^{1}$.

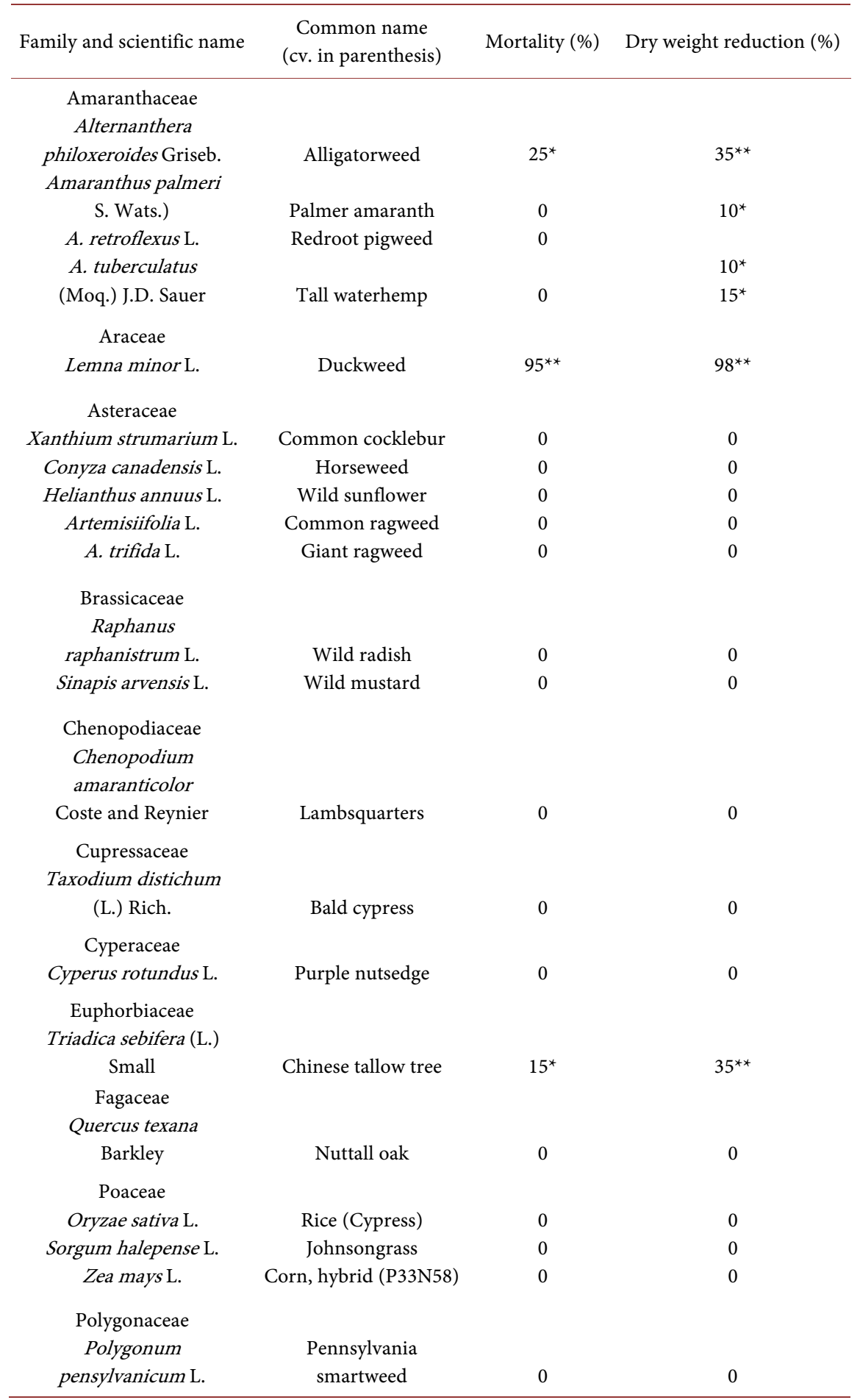

${ }^{1}$ Seedlings ( 2 - 3 leaf growth stage) were sprayed until runoff with a fungal suspension of $1.0 \times 10^{8} \mathrm{cfu}$ 's $/ \mathrm{ml}$ containing Silwet L-77 surfactant $(0.20 \%, \mathrm{v} / \mathrm{v})$ and incubated in a dew chamber for $16 \mathrm{~h}$ at $25^{\circ} \mathrm{C}$. Control plants for each species were treated with surfactant only; giant salvinia was included in all tests to verify pathogen virulence. Herbaceous plants were rated 14 days after treatment for mortality, and dry weight reductions were recorded after plants (excised at the soil surface) were oven-dried at $80^{\circ} \mathrm{C}$ for 3 days. Woody species were obtained from nurseries and averaged $25-35 \mathrm{~cm}$ tall at times of inoculation. ${ }^{*}$ Significant at the $95 \%$ level; ${ }^{* *}$ significant at the $99 \%$ level according to the t-test. 
Table 2. Biological control of $S$. molesta with a $B$. rhodina mycelial formulation under field conditions.

\begin{tabular}{ccc}
\hline Treatment & Plant mortality (\%) & Dry weight reduction (\%) \\
\hline Untreated control & 0 & 0 \\
B. rhodina mycelium & & \\
+ Silwet L-77 & $95^{* *}$ & $98^{* *}$ \\
\hline
\end{tabular}

" Denotes significant difference from untreated controls at the $99 \%$ level according to the t-test.

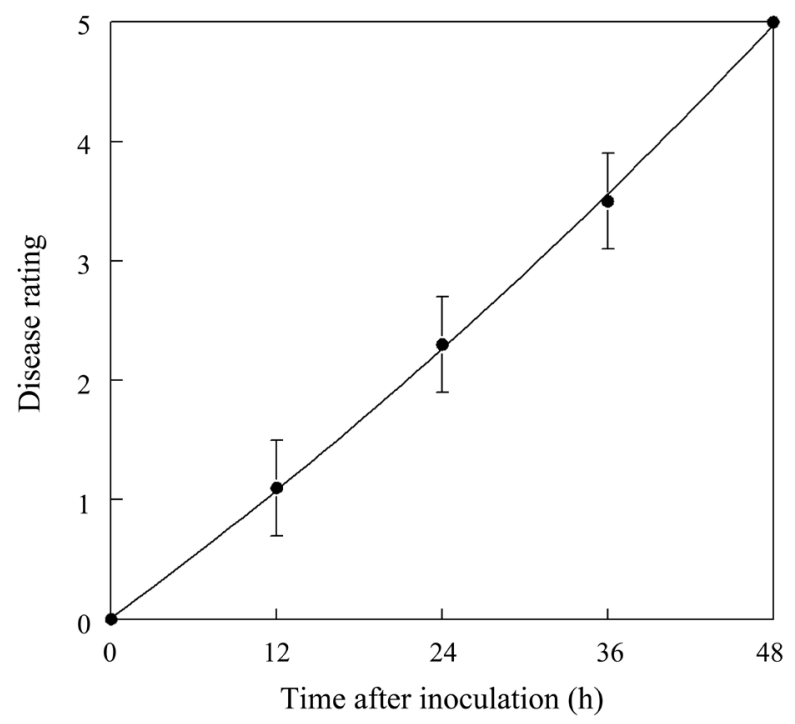

Figure 2. Disease progression of $B$. rhodina infecting $S$. molesta. Error bars $= \pm 1$ S.E.M. The relationship for effect of inoculum concentration on mortality is second degree polynomial relationship where: $Y=-0.014+0.84 X+0.001 X^{2}, R^{2}=0.99$.

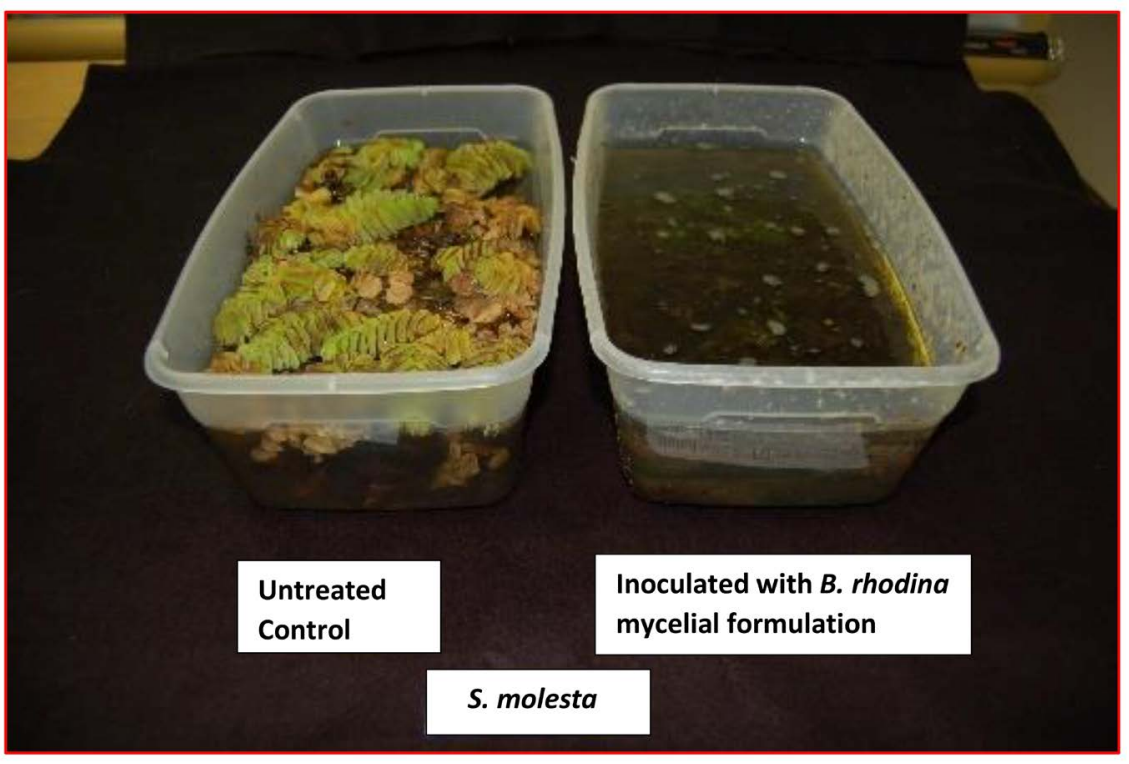

Figure 3. S. molesta controlled $100 \%$ after $48 \mathrm{~h}$ by a mycelial formulation of $B$. rhodina. 


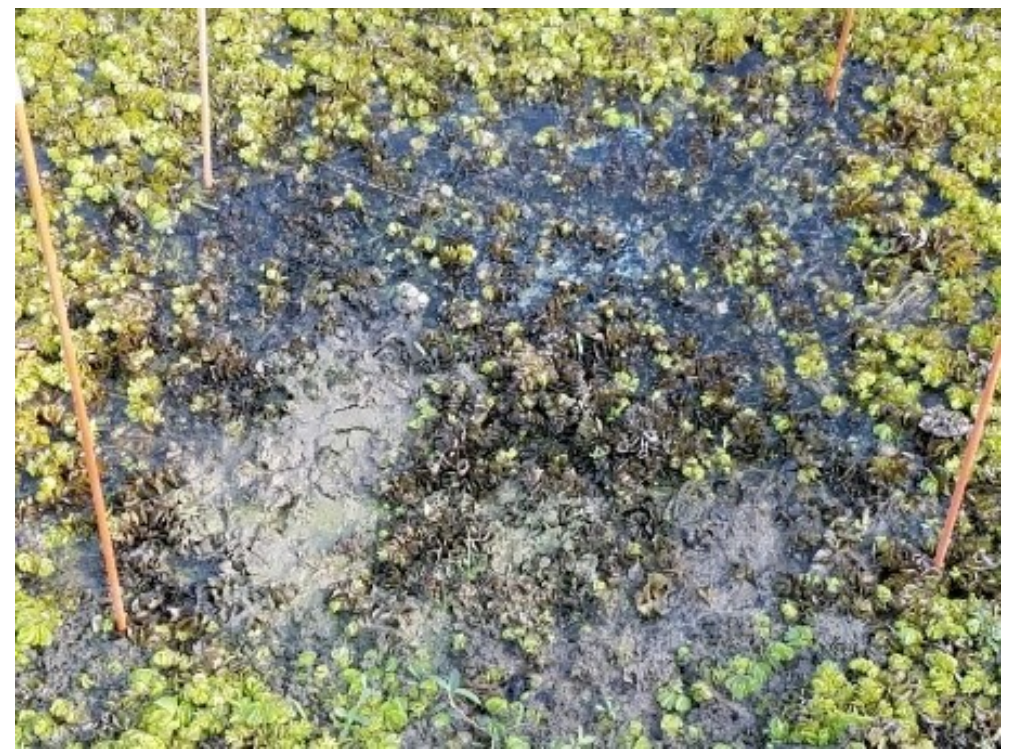

Figure 4. Giant Salvinia controlled $\sim 95 \%$ after $72 \mathrm{~h}$ by a $B r$ mycelial formulation $48 \mathrm{HAT}$ in a naturally-infested pond in Louisiana. Markers are $1.0 \mathrm{~m}$ apart.

\section{Conclusion}

In conclusion, this isolate of Botryosphaeria rhodina mycelium is highly effective for biological control of Salvinia molesta. We found that Brfungal mycelium was highly infective to host weeds and could be rapidly produced $(48 \mathrm{~h})$ in inexpensive agricultural products, (e.g., soy flour-cornmeal medium liquid media) in shake flasks or fermenters. A surfactant (Silwet L-77) was required for $B r$ to infect and kill plants. This formulation was also highly efficacious against other problematic aquatic weeds, such as $S$. minima, Azolla filiculoides, and Lemna minor. Infection and mortality occurred rapidly (within $48 \mathrm{~h}$ after treatment), and re-growth of treated plants did not occur. The $B r$ fungal mycelium/surfactant formulation effectively controlled $S$. molesta under field conditions. Future studies can be envisioned, including more extensive host range tests with other aquatic and terrestrial weeds (and crops), as well as interactions with herbicides and tests for efficacy in the field.

\section{Conflicts of Interest}

The authors declare no conflicts of interest regarding the publication of this paper.

\section{References}

[1] Ray, P. and Hill, M.P. (2013) Microbial Agents for Control of Aquatic Weeds and Their Role in Integrated Management. CAB Reviews, 8, 1-9. https://doi.org/10.1079/PAVSNNR20138014

[2] Westbrooks, R. (2010) Statement of Dr. Randy Westbrooks, Invasive Species Prevention Specialist, U.S. Geological Survey, Department of the Interior, before the House Committee on Natural Resources Subcommittee on Fisheries, Wildlife, 
Oceans and Insular Affairs Oversight Hearing on Efforts to Control and Eradicate Giant Salvinia, June 27, 2010.

[3] Johnson, D. (1995) Giant salvinia Found in South Carolina. Aquatics, 17, 22.

[4] Broom, B. (2018) Barnett Reservoir Board Takes Serious Action to Combat Invasive Giant Salvinia: Invasive Aquatic Plant Threatens Popular Lake. Mississippi Clarion Ledger, October 18, 2018.

[5] Peck, J.H. (2011) New and Noteworthy Additions to the Arkansas Fern Flora. Phytoneuron, 30, 1-33.

[6] Bailey, J.D. (2020) Invasive Plant Species Giant Salvinia Found in Lake Columbia. Magnolia (AR) Banner News, January 6, 2020.

[7] Holm, L., Plucknett, D., Pancho, J. and Herberger, J. (1977) The World's Worst Weeds-Distribution and Biology. University of Hawaii Press, Honolulu, 609 p.

[8] Thomas, P.A. and Room, P.M. (1986) Taxonomy and Control of Salvinia molesta. Nature, 320, 581-584. https://doi.org/10.1038/320581a0

[9] Pancho, J.V. and Soerjani, M. (1978) Aquatic Weeds of Southeast Asia. National Publication Cooperative, Quezon City.

[10] Creagh, C. (1991) A Marauding Weed in Check. Ecos, 70, 26-29.

[11] Lounibos, L.P., Larson, V.L. and Morris, C.D. (1990) Parity, Fecundity, and Body Size of Mansonia dyari in Florida. Journal of the American Mosquito Control Association, 6, 121-126.

[12] Room, P.M. and Julien, M.H. (1995) Salvinia molesta D.S. Mitchell. In: Groves, R.H., Shepherd, R.C.H. and Richardson, R.G., Eds., The Biology of Australian Weeds, Volume 1, R.G. and F.J. Richardson, Melbourne, 217-230.

[13] Van Oosterhout, E. (2006) Salvinia Control Manual-Management and Control Options for Salvinia (Salvinia molesta) in Australia. NSW Department of Primary Industries.

[14] Glomski, L.M. and Getsinger (2006) Carfentrazone-ethyl for Control of Giant Salvinia. Journal of Aquatic Plant Management, 44, 136-138.

[15] Anonymous (2009) Louisiana Chemical Weed Management Guide. Louisiana State University Agricultural Center Publication No. 165, 192 p.

[16] Glomski, L.M. and Mudge, C.R. (2013) Effect of Subsurface and Foliar Applications of Bispyribac-Sodium on Water Hyacinth, Water Lettuce, and Giant Salvinia. Journal of Aquatic Plant Management, 51, 62-65.

[17] Mitchell, D.S. and Tur, N.M. (1975) The Rate of Growth of Salvinia molesta (S. auriculata Auct.) in Laboratory and Natural Conditions. Journal of Applied Ecology, 12, 213-225. https://doi.org/10.2307/2401730

[18] Center, T.D., Tipping, P.W., Goolsby, J.A. and Everitt, J.H. (2001) Attack on Giant Salvinia. USDA-ARS Publication.

https://agresearchmag.ars.usda.gov/2001/nov/giant/

[19] Forno, I.W. (1983) Native Distribution of the Salvinia auriculata Complex and Keys to Species Identification. Aquatic Botany, 17, 71-83. https://doi.org/10.1016/0304-3770(83)90019-0

[20] Forno, I.W., Sands, D.P.A. and Sexton, W. (1983) Distribution, Biology, and Host Specificity of Cyrotobagous singularis (Hustache) (Coleoptera: Curculionidae), for the Biological Control of Salvinia molesta (Mitchell). Bulletin of Entomological Research, 73, 85-95. https://doi.org/10.1017/S0007485300013821

[21] Flores, D. and Carlson, J.W. (2006) Biological Control of Giant Salvinia in East 
Texas Waterways and the Impact on Dissolved Oxygen Levels. Journal of Aquatic Plant Management, 44, 115-121.

[22] Tipping, P.W. and Center, T.D. (2003) Cyrtobagous salviniae (Coleoptera: Curculionidae) Successfully Overwinters in Texas and Louisiana. Florida Entomolology, 86, 92-93. https://doi.org/10.1653/0015-4040(2003)086[0092:CSCCSO]2.0.CO;2

[23] Tipping, P.W. and Center, T.D. (2005) Influence of Plant Size and Species on Preference of Cyrtobagous salviniae Adults from Two Populations. Biological Control, 32, 263-268. https://doi.org/10.1016/j.biocontrol.2004.10.005

[24] Tipping, P.W., Martin, M.R., Center, T.D. and Davern, T.M. (2008) Suppression of Salvinia molesta Mitchell in Texas and Louisiana by Cyrtobagous salviniae Calder and Sands. 2008. Aquatic Botany, 88, 196-202.

https://doi.org/10.1016/j.aquabot.2007.10.010

[25] Parys, K.A. and Johnson, S.J. (2013) Biological Control of Common Salvinia (Salvinia minima) in Louisiana Using Cyrtobagous salviniae (Coleoptera: Curculionidae). Florida Entomologist, 96, 10-18. https://doi.org/10.1653/024.096.0102

[26] Lumbsch, T.H. and Huhndorf, S.M. (2007) Outline of Ascomycota-2007. Myconet, The Field Museum, Department of Botany, Chicago, 13, 1-58.

[27] Freund, R.J. and Wilson, W.J. (1997) Statistical Methods. Academic Press, Cambridge.

[28] Sandrin, T.R., TeBeest, D.O. and Weidemann, G.J. (2003) Soybean and Sunflower Oils Increase the Infectivity of Colletotrichum gloeosporioides $\mathrm{f}$. sp. aeschynomene to Northern Jointvetch. Biological Control, 26, 244-252. https://doi.org/10.1016/S1049-9644(02)00156-1

[29] Steele, R.G.D., Torrey, J.H. and Dickeys, D.A. (1997) Multiple Comparisons. In: Principles and Procedures of Statistics-A Biometrical Approach, McGraw Hill, New York, 365. 